\title{
IMPLEMENTASI KEBIJAKAN PERATURAN PEMERINTAH NOMOR 68 TAHUN 2002 TENTANG KETAHANAN PANGAN DI KABUPATEN NUNUKAN
}

\author{
Nurpatimah $^{1}$, Abdul Mahsyar ${ }^{2}$, Alimuddin Said $^{3}$ \\ ${ }^{1)}$ Mahasiswa, Jurusan Ilmu Administasi Negara Unismuh Makassar \\ 2) Dosen, Jurusan Ilmu Administasi Negara Unismuh Makassar \\ 3) Dosen, Jurusan Ilmu Administasi Negara Unismuh Makassar
}

\begin{abstract}
ABTRACK
The purpose of this research was to know the implementation of government regulation policy number 68 year 2002 about food security in Nunukan Regency and to know the supporting factor and the obstacle factor of the implementation of government regulation policy on food security in Nunukan Regency. The type of research used was descriptive qualitative research. The study used a phenomological type. Technique of collecting data used instrument in the form of interview, observation and documentation. The reselts of the research indicated that there werefour things related in this case, namely

(1)Implementation of government regulation policy number 68 year 2002 regarding food security in Nunukan Regency had been running well enough, it just needed little attention from the government for farmer assistance, it must always be on time so that farmers were not difficult in managing food. (2)Commitment built by the agricultural service and food security in Nunukan Regency had been running well,(3)Control of organization or supervision had been done well,(4)The behavior of target group dimension included positive or negative response of society in supporting or not supporting policy. The people who did not join the farmer groups gave response negatively to this policy.
\end{abstract}

Keywords:Implementation, Food Security.

\begin{abstract}
ABSTRAK
Tujuan penelitian adalah untuk mengetahui implementasi kebijakan peraturan pemerintah nomor 68 tahun 2002 tentang ketahanan pangan di kabupaten nunukan dan untuk mengetahui faktor pendukung dan faktor penghambat implementasi kebijakan peraturan pemerintah tentang ketahanan pangan di kabupaten nunukan. Jenis penelitian yang digunakan adalah jenis penelitian deskriptif kualitatif. Penelitian menggunakan tipe fenomologis. Teknik pengumpulan data menggunakan instrumen berupa wawancara, observasi dan dokumentasi. Hasil penelitian menunjukkan bahwa ada lima yang terkait dalam hal ini yaitu (1)Implementasi kebijakan peraturan pemerintah nomor 68 tahun 2002 tentang ketahanan pangan di kabupaten nunukan sudah berjalan cukup baik, hanya perlu sedikit perhatian dari pemerintah untuk bantuan tani harus selalu tepat waktu agar petani tidak kesulitan dalam mengelolah pangan.(2)Komitmen yang dibangun oleh dinas pertanian dan ketahanan pangan di kabupaten nunukan sudah berjalan cukup baik,(2) Kontrol organisasi atau pengawasan yang dilakukan sudah baik.(4)Perilaku kelompok sasaran dimensinya mencakup respon positif atau negatif masyarakat dalam mendukung atau tidak mendukung kebijakan. Hanya masyarakat yang tidak bergabung di kelompok tani yang merespon negatif dengan adanya kebijakan ini.
\end{abstract}

Kata Kunci:Implementasi, Ketahanan Pangan 


\section{PENDAHULUAN}

Indonesia adalah negara agraris dimana mata pencaharian mayoritas penduduknya dengan bercocok tanam. Secara geografis Indonesia yang juga merupakan negara kepulauan memiliki potensi alam yang besar tidak hanya dalam bidang kelautan tapi juga dalam pengolahan pertanian. Potensi pertanian Indonesia yang tinggi salah satunya disebabkan wilayah Indonesia yang memiliki wilayah daratan sepertiga dari luas keseluruhan ini dilewati barisan pegunungan dunia. Hal ini menyebabkan wilayah daratan Indonesia sangat subur. Oleh karena itu, tidak mengherankan jika sebagian besar penduduk Indonesia bermata pencaharian sebagai petani. Itulah mengapa selain disebut sebagai negara maritim, Indonesia juga disebut sebagai negara agraris

Ketahanan pangan ini menjadi semakin penting karena pangan bukan hanya merupakan kebutuhan dasar (basic need) tetapi juga merupakan hak dasar (basic right) bagi setiap umat manusia yang wajib dipenuhi. Oleh karena pangan merupakan hak dasar itulah, maka negara telah mendapatkan haknya atas pangan(Hariyadi, dkk, $2009: 1$ ).

Menurut Achmad Suryana (2005:6) Permasalahan utama yang dihadapi dalam mewujudkan ketahanan pangan di Indonesia saat ini adalah bahwa pertumbuhan permintaan pangan yang lebih cepat dari pertumbuhan penyediaan.

Permintaan yang meningkat merupakan resultante dari peningkatan jumlah penduduk, pertumbuhan ekonomi, peningkatan daya beli masyarakat, dan perubahan selera. Sementara itu, pertumbuhan kapasitas produksi pangan cukup lambat dan stagnan, karena: (a) adanya kompetisi dalam pemanfaatan sumberdaya lahan dan air, serta (b) stagnansi pertumbuhan produktivitas lahan dan tenaga kerja pertanian. Ketidak seimbangan pertumbuhan permintaan dan pertumbuhan kapasitas produksi nasional mengakibatkan kecenderungan pangan nasional dari 
impor meningkat, dan kondisi ini diterjemahkan sebagai ketidak mandirian penyediaan pangan. Dengan kata lain hal ini dapat diartikan pula penyediaan pangan (dari produksi domestik) yang tidak stabil.

Namun demikian di kabupaten nunukan secara keseluruhan sebenarnya dapat dikatakan sudah aman dari aspek produksinya, terutama dalam hal jumlah produksinya. Secara jumlah, kabupaten nunukan mengalami kelebihan dan sudah mencukupi, terutama produksi padi (beras). Namun masalah yang masih dihadapi kabupaten nunukan adalah adanya ancaman ahli fungsi lahan pertanian ke non pertanian. Ancaman terhadap produksi lainya adalah kegairahan petani, kalau petani tidak bergairah dengan usaha taninya, petani akan beralih ke usaha lainya seperti menjadi nelayan, TKI ke luar negeri atau usaha non pertanian lainnya. "segala yang dikerjakan pemerintah, mengapa mereka melakukan, dan perbedaan yang dihasilkannya (what government did, why they do it, and what differences it makes)". Dalam pemahaman bahwa "keputusan" termasuk juga ketika pemerintah memutuskan untuk "tidak memutuskan" atau memutuskan untuk "tidak mengurus" suatu isu, maka pemahaman ini juga merujuk pada definisi Thomas R. Dye dalam Tilaar dan Nugroho (2008:185) yang menyatakan bahwa kebijakan publik merupakan "segala sesuatu yang dikerjakan dan tidak dikerjakan oleh pemerintah".

Senada dengan definisi Dye, George C. Edwards III dan Ira Sharkansky dalam Suwitri (1980) juga menyatakan bahwa kebijakan publik merupakan: Apa yang dinyatakan dan dilakukan atau tidak dilakukan oleh pemerintah yang dapat ditetapkan dalam peraturan perundang-undangan atau dalam policy statement yang berbentuk pidato-pidato dan wacana yang diungkapkan pejabat politik dan pejabat pemerintah yang segera ditindaklanjuti dengan programprogram dan tindakan pemerintah.

Makna implementasi menurut Daniel A. Mazmanian dan Paul Sabatier (1979) sebagaimana dikutip 
dalam buku Solihin Abdul Wahab (2008:65), mengatakan bahwa : "implementasi adalah memahami apa yang senyatanya terjadi sesudah suatu program dinyatakan berlaku atau dirumuskan merupakan suatu fokus perhatian implementasi kebijaksanaan yakni kejadiankejadian dan kegiatan-kegiatan yang timbul sesudah disahkannya pedoman-pedoman kebijksanaan Negara yang mencakup baik usahausaha untuk mengadministrasikannya maupun untuk menimbulkan akibat|dampak nyata bagi masyarakat atau kejadian-kejadian".

\section{Van Meter dan Van Horn}

(Budi Winarno,2007;102) membatasi implementasi kebijakan sebagai tidakan-tindakan yang dilakukan individu-individu atau kelompokkelompok pemerintah maupun swasta yang arahkan untuk mencapai tujuan-tujuan yang telah ditetapkan dalam keputusan-keputusan sebelumnya, Micahel Howlet dan M. Ramesh (1995;11) dalam buku

Subarsono (2006;13), bahwa "implementasi kebijakan adalah proses untuk melakukan kebijakan supaya mencapai hasil.". Dari defenesi diatas dapat diketahui bahwa imlementasi kebijakan terdiri dari tujuan atau sasaran kebijakan,aktivitas atau kegiatan pencapaian tujuan,dari hasil kegiatan. Sehingga dapat disimpulkan bahwa implementasi merupakan suatu proses yang dinamis, dimana suatu pelaksana kebijakan melakuakan suatu aktivitas atau kegiatan,sehingga pada akhirnya akan mendapatkan suatu hasil yang sesuai dengan tujuan atau sasaran kebijakan itu sendiri. Kebrhasilan suatu implementasi kebijakan dapat diukur atau dilihat dari proses dan pencapaian tujuan hasil akhir (output), yaitu: tercapai atau tidaknya tujuan-tujuan yang ingin diraih.

Defenisi diatas dapat diketahui bahwa implementasi kebijakan terdiri dari tujuan atau sasaran kebijakan, aktivitas, atau kegiatan pencapaian tujuan, dari hasil kegiatan. Sehingga dapat disimpulkan bahwa implementasi merupakan suatu proses yang dinamis, dimana pelaksana kebijakan melakukan suatu aktivitas atau 
kegiatan, sehingga pada akhirnya Menurut Lassa akan mendapatkan suatu hasil yang sesuai dengan tujuan atau sasaran kebijakan itu sendiri. Keberhasilan suatu implementasi kebijakan dapat diukur atau dilihat dari proses dan pencapaian tujuan hasil akhir (output), yaitu: tercapai atau tidaknya tujuan-tujuan yang ingin diraih.

Dalam UU/No 7/Tahun 1996 dan disempurnakan menjadi UU/No 68/Tahun 2002 tentang ketahanan pangan dijelaskan bahwa: “ Ketahanan Pangan adalah kondisi terpenuhinya pangan bagi rumah tangga yang tercermin dari tersedianya pangan yang cukup, baik jumlah maupun mutunya, aman, merata dan terjangkau. Sedangkan pangan adalah segala sesuatu yang berasal dari sumber hayati dan air, baik yang diolah maupun tidak diolah yang diperuntukan sebagai makanan atau minuman bagi konsumsi manusia, termasuk bahan tambahan pangan, bahan baku pangan, dan bahan lain yang digunakan dalam proses penyiapan, pengolahan, atau pembuatan makanan atau minuman." 
pangan yang rapuh, terbukti dengan tingginya tingkat kekurangan pangan dan gizi buruk.

$$
\text { Menurut Syahyuti }
$$

Ketahanan pangan merupakan

paradigma yang digunakan pemerintah dalam pemenuhan pangan penduduk dan pembangunan pertanian pangan umumnya. Pendekatan kedaulatan pangan mungkin dapat melengkapi dan menyempurnakan konsep ketahanan pangan. Konsep ketahanan pangan banyak mengalami perubahan. Semula ditekankan pada penyedia pangan yang cukup (1960-an dan 1970-an), kemudian memasukkan jaminan akses (1983), lalu diperluas dengan memasukkan kemiskinan, pendapatan, bencana alam, krisis ekonomi, dan konflik (1986). Priode 1990-an memasukkan keamanan pangan (food safety) dan kekurangan protein dan energi.

Ketahanan pangan harus mencakup faktor ketersediaan, distribusi, dan konsumsi. Faktor ketersediaan pangan berfungsi menjamin pasokan pangan untuk memenuhi kebutuhan seluruh penduduk, baik dari segi kuantitas, kualitas, keragaman dan keamanannya. Distribusi berfungsi mewujudkan sistem distribusi yang efektif dan efisien untuk menjamin agar masyarakat dapat memperoleh pangan dalam jumlah, kualitas dan keberlanjutan yang cukup dengan harga yang terjangkau. Sedangkan

Faktor konsumsi berfungsi mengarahkan agar pola pemanfaatan pangan secara nasional memenuhi kaidah mutu, keragaman, kandungan gizi, kemananan dan kehalalannya. Situasi ketahanan pangan di negara kita masih lemah. Hal ini ditunjukkan antara lain oleh: (a) jumlah penduduk rawan pangan (tingkat konsumsi < $90 \%$ dari rekomendasi $2.000 \mathrm{kkal} / \mathrm{kap} / \mathrm{hari}$ ) dan sangat rawan pangan (tingkat konsumsi $<70 \%$ dari rekomendasi) masih cukup besar, yaitu masingmasing 36,85 juta dan 15,48 juta jiwa untuk tahun 2002; (b) anakanak balita kurang gizi masih cukup besar, yaitu 5,02 juta dan 5,12 juta jiwa untuk tahun 2002 dan 2003 (Ali Khomsan, 2003). 


\section{METODE PENELITIAN}

Waktu yang dibutuhkan penulis dalam penelitian ini selama 2 bulan dan bertempat di Dinas Pertanian dan Ketahanan Pangan Kabupaten Nunukan. Penelitian ini bermaksud mengetahui bagaimana implementasi kebijakan peraturan pemerintah nomor 68 tahun 2002 tentang ketahanan pangan. Jenis penelitian adalah kualitatif dengan menggambarkanpengimplementasian kebijakan peraturan pemerintah nomor 68 tahun 2002 tentang ketahanan pangan di kabupaten nunukan . Penelitian menggunakan tipe fenomologi. Sumber data adalah data primer dan data sekunder. Informan penelitian yaitu Kepala Dinas Pertanian dan Ketahanan Pangan, Sekretaris Dinas Pertanian dan Ketahanan Pangan, staf Dinas Pertanian dan Ketahanan Pangan, Anggota LSM, dan Masyarakat. Dalam penelitian ini, pengumpulan data dilakukan melalui beberapa teknik yaitu wawancara, observasi dan dokumentasi. Teknik pengabsahan data yaitu dengan teknik triangulasi. Teknik analisa data yaitu Pengumpulan informasi melalui wawancara, Reduksi data, Penyajian data, dan penarikan kesimpulan atau verifikasi.

\section{HASIL DAN PEMBAHASAN}

Implementasi merupakan tindakan-tindakan untuk mencapai tujuan yang telah digariskan dalam keputusan kebijakan. Tindakan tersebut baik dilakukan oleh individu, pejabat pemerintah ataupun swasta. Dunn mengistilahkan Implementasi secara lebih khusus, dalam bukunya yang berjudul Analisis Kebijakan Publik.

Menurutnya Implementasi Kebijakan (Police Implementation) adalah pelaksanaan pengendalian aksi-aksi kebijakan di dalam kurun waktu tertentu. Jadi Implementasi itu merupakan tindakan-tindakan yang dilakukan oleh pemerintah untuk mencapai tujuan yang telah ditetapkan dalam suatu keputusan kebijakan. Akan tetapi, pemerintah dalam membuat kebijakan juga harus mengkaji terlebih dahulu apakah kebijakan tersebut dapat memberikan dampak yang buruk atau tidak kepada masyarakat. Hal tersebut 
bertujuan agar suatu kebijakan tidak bertentangan dengan masyarakat apalagi sampai merugikan masyarakat.

Merujuk pada penjelasan diatas, maka peneliti melihat sejauh mana realisasi dan pelaksanaan suatu keputusan kebijakan yang ada di peraturan pemerintah nomor 68 tahun 2002 tentang ketahanan pangan sesuai isi peraturan pemerintah pasal 2 no (2) tentang sistem produksi pangan, teknologi produksi pangan, sarana dan prasarana produksi pangan dan lahan produktif

Sistem produksi pangan yang baik merupakan satu faktor yang paling penting untuk memenuhi standar mutu atau persyaratan yang ditetapkan untuk pangan. Sistem produksi pangan yang baik sangat berguna bagi kelangsungan hidup industri pangan baik berskala kecil, sedang, maupun berskala besar. Melalui sistem produksi pangan yang baik industri pangan dapat menghasilkan pangan yang bermutu, dan aman untuk dikonsumsi, kepercayaan masyarakat niscaya akan meningkat, dan industri pangan yang bersangkutan akan berkembang dengan pesat. Dengan berkembangnya industri pangan yang menghasilkan pangan yang bermutu dan aman untuk dikonsumsi, maka masyarakat pada umumnya akan terlindung dari penyimpangan mutu pangan dan bahaya yang mengancam kesehatan. (BPOM:2004),

Dalam peraturan pemerintah nomor 68 tahun 2002 tentang ketahanan pangan yang di maksud dengan sistem produksi pangan adalah metode/tata cara dalam kegiatan atau proses menghasilkan, menyiapkan, mengolah, membuat, mengawetkan,mengemas, mengemas kembali, dan/atau mengubah bentuk pangan, pemerintah selalu berusaha untuk meningkatkan ketahanan pangan di kabupaten nunukan demi kelangsungan hidup masyarakatnya. Ketahanan pangan merupakan hal yang sangat penting karena ketahanan pangan diselenggarakan untuk memenuhi kebutuhan konsumsi rumah tangga yang terus berkembang dari waktu ke waktu.

Masyarakat tani di kabupaten nunukan memanen hasil tanaman 
pangannya pada waktu yang tepat agar mutu hasil produk tanaman pangan dapat optimal pada saat dikonsumsi. Masyarakat tani di kabupaten nunukan juga memanen tanaman pangan harus sesuai dengan teknik dan anjuran baku untuk setiap jenis tanaman sehingga diperoleh mutu hasil panen yang tinggi, tidak rusak, tetap segar dalam waktu lama, serta tanaman pangan mereka kemaskan di suatu wadah yang akan digunakan untuk menyimpan hasil tanaman pangan mereka,

Pengeringan adalah salah satu cara untuk mengawetkan hasil panen pangan mereka. Pengeringan adalah suatu cara untuk mengeluarkan atau menghilangkan sebagian air dari suatu bahan dengan menguapkan sebagian besar air yang dikandung melalui penggunaan energi panas. Biasanya, kandungan air bahan tersebut dikurangi sampai batas sehingga mikroorganisme tidak dapat tumbuh lagi di dalamya. Keuntungan pengeringan adalah bahan menjadi lebih awet dan volume bahan menjadi lebih kecil sehingga mempermudah dan menghemat ruang pengangkutan dan pengepakan, berat bahan juga menjadi berkurang sehingga memudahkan transpor, dengan demikian di harapkan biaya produksi menjadi lebih murah. Di samping ada keuntungan-keuntungannya, pengeringan juga mempunyai beberapa kerugian yaitu karena sifat asal bahan yang dikeringkan dapat berubah, misalnya bentuknya, sifatsifat fisik dan kimianya, penurunan mutu dan sebagainya.

Tahun 2014, total produksi serealia pokok dan biji-bijian mencapai 51.878 ton terdiri dari padi 48.127 ton, kacang tanah 1.385 ton, dan kacang hijau 2.366 ton. Total produksi tahun 2010 sebesar 40.985 ton menjadi 51.878 ton pada tahun 2014 . Sebaran total produksi serealia dan biji-bijian selama 5 tahun terbesar terjadi pada tahun 2014, yaitu sebesar 51.878 ton dan yang terkecil pada tahun 2010 dengan produksi sebesar 40.985 ton.

Teknologi produksi pangan adalah suatu teknologi yang menerapkan ilmu pengetahuan tentang bahan pangan khususnya setelah panen (pasca panen) guna memperoleh manfaatnya seoptimal 
mungkin sekaligus dapat Masyarakat pada masa lalu sudah meningkatkan nilai tambah dari dapat memanfaatkan sumber daya pangan tersebut. Dalam teknologi alam untuk memenuhi kebutuhan pangan, dipelajari sifat fisis, mikrobiologis, dan kimia dari bahan pangan dan proses yang mengolah bahan pangan tersebut. Spesialisasinya beragam, di mereka. Namun, teknologi yang digunakannya masih sangat sederhana. Dengan menggunakan alat sederhana, memerlukan tenaga besar dan hasilnya pun terbatas.

antaranya pemrosesan, pengawetan, pengemasan, penyimpanan, dan sebagainya.

Sejarah teknologi pangan dimulai ketika Nicolas Appert mengalengkan bahan pangan, sebuah proses yang masih terus berlangsung hingga saat ini. Namun ketika itu, Nicolas Appert mengaplikasikannya tidak berdasarkan ilmu pengetahuan terkait pangan. Aplikasi teknologi pangan berdasarkan ilmu pengetahuan dimulai oleh Louis Pasteur ketika mencoba untuk mencegah kerusakan akibat mikroba pada fasilitas fermentasi anggur setelah melakukan penelitian terhadap anggur yang terinfeksi.

Teknologi produksi pangan merupakan alat dan cara yang digunakan manusia untuk menghasilkan barang atau jasa.

Ketika ilmu pengetahuan berkembang maka berkembang pula teknologi. Alat-alat yang memudahkan pekerjaan manusia banyak ditemukan. Alat-alat tersebut sangat membantu dalam menyelesaikan pekerjaan manusia. Dengan alat yang lebih modern pekerjaan dapat diselesaikan lebih cepat, ringan, dan hasilnya pun lebih banyak. Masyarakat Indonesia sejak jaman dahulu telah mengenal teknologi. Namun, jenis teknologi yang masih digunakan masih sederhana sekali, kegiatan produksi erat kaitannya dengan industri. Teknologi industri adalah suatu usaha mlakukan kegiatan yang merubah dari suatu atau beberapa barang mentah menjadi barang setengah jadi atau barang jadi. Teknologi industri menggunakan 
teknologi produksi, yaitu teknologi yang digunakan dalam proses produksi. Teknologi produksi jaman dahulu berbeda dengan jaman sekarang.

$\begin{array}{cccc} & \text { Pertanian merupakan sektor } \\ \text { yang sangat penting untuk }\end{array}$ menunjang kehidupan manusia sejak masa prasejarah hingga saat ini. Begitu juga dengan Indonesia, pertanian tidak bisa dilepaskan karena Indonesia sampai saat ini masih merupakan negara agraris. Meskipun saat ini Indonesia sedang bergerak menuju negara perindustrian, sektor pertanian masih memegang perekonomian Indonesia. (Mugnisiah:1995)

Sarana produksi pangan yang baik biasanya digunakan baik dalam proses awal pembukaan lahan, budidaya pertanian seperti pemupukan, pemeliharaan tanaman dan lain-lain sampai dengan proses pemanenan. Sehingga dapat dikatakan bahwa tujuan utama dari sarana produksi dalam bidang pertanian adalah untuk meningkatkan produktivitas kerja petani dan merubah hasil yang sederhana menjadi lebih baik. saran produksi pangan pertanian terdiri dari bahan yang meliputi, benih, pupuk, pestisida, dan zat pengatur tumbuh yang digunakan untuk melaksanakan produksi pertanian. Sarana-sarana tersebut harus sudah dipersiapkan sebelum memulai kegiatan sarana budidaya tanaman. (Djakfar:1990)

Benih adalah biji tanaman yang digunakan untuk tujuan penanaman. Benih merupakan bentuk yang masih dalam keadaan terkekang. Benih merupakan komponen agronomi dan komponen penting didalam pengelolaan lapangan produksi sebagai komponn, masalah benih berorientasi kepada penerapan kaidah-kaida ilmiah.(Acne:1986).

Pupuk adalah senyawa yang mengandung unsure hara yang diberikan pada tanaman dengan dosis tertentu. Bagian yang tidak mengandung unsure hara tersebut akan menurunkan kadar hara dalam pupuk tersebut.(Basri:1991)

$$
\text { Zat pengatur tumbuh }
$$
merupakan senyawa organic yang bukan hara, dalam jumlah sedikit 
dapat mendorong pertumbuhan tanaman. Penggunaan zat pengatur tumbuh dapat menghemat biaya produksi karena dgunakan dalam taksiran (dosis) rendah. Beberapa zat pengatur tumbuh dan hormone yang sudah kita kenal ada 5, yaitu auksin, giberalin, sitokini, asam absisat, dan etilen.(Djakfar:1990)

Pestisida adalah substansi kimia yang digunakan untuk membunuh atau mengendalikan hama. Kata pestisida berasal dari kata pest meliputi hama penyakit secara luas dan kata sida berasal dari kata ceado yang artinya membunuh.

Penggunaan pestisida dalam pertanian telah menunjukkan

kemampuaanya didalam menanggulangi atau mengurangi merosotnya hasil akibat serangan hama dan penyakit.(Soedyanto:1978) Jika dilihat dari asal katanya, pestisida atau pesticide berasal daro kata pest yang berarti hama dan cide yang berarti mematikan atau racun. Jadi pestisida adalah racun hama. Secara umum pestisida dapat didefenisikan sebagai bahan yang digunakan untuk mengendalikan populasi jasad yang dianggap sebagai pest yang secara langsung maupu tidak langsung merugikan kepentingan manusia.(Munaf:1997) Dinas Pertanian dan Ketahanan pangan di kabupaten nunukan melaksanakan peningkatan ketahanan pangan di kabupaten nunukan melakukan kegiatan seperti infrastruktur pertanian. Infrastruktur (prasarana) pertanian merupakan suatu bangunan fisik (struktur) pendukung pengembangan pertanian. Infrastruktur memegang peranan penting sebagai salah satu roda penggerak pertumbuhan ekonomi dan pembangunan. Keberadaan infrastruktur yang memadai sangat diperlukan. Prasarana fisik atau sering disebut dengan infrastruktur merupakan bagian yang sangat penting dalam system pelayanan masyarakat. Berbagai fasilitas fisik merupakan hal yang vital guna mendukung berbagai kegiatan pemerintahan, perekonomian, industri dan kegiatan social di masyarakat dan pemerintah.

Lahan memiliki beberapa pengertian yang diberikan baik itu oleh FAO maupun pendapat para ahli. Menurut Purwowidodo (1983) 
lahan mempunyai pengertian yaitu suatu lingkungan fisik yang mencakup iklim, relief tanah, hidrologi, dan tumbuhan yang sampai pada batas tertentu akan mempengaruhi kemampuan lahan. Laha juga diartikan sebagai permukaan daratan dengan bendabenda padat, cair, bahkan gas.(Rafi'I:1985). Defenisi lain juga dikemukakan oleh Arsyad ( 1989) Lahan diartikan sebagai lingkungan fisik yang terdiri atas iklim, relief, tanah, air dan vegetasi serta benda yang diatasnya sepanjang ada pengaruhnya terhadap pengguna lahan, termasuk didalamnyahasil kegiatan manusia dimasa lalu dan sekarang seperti hasil reklamasi laut, pembersi vegetasi dan juga hasil yang merugikan seperti yang tersalinasi, selain itu lahan memiliki pengertian yang hanpir serupa

dengan sebelumnya bahwa pengertian lahan adalah suatu daerah dipermukaan bumi dengan sifat-sifat tertentu yang meliputi biosfer, atmosfer, tanah, lapisan geogologi, hidrologi, populasi tanaman dan hewan serta hasil kegiatan manusia masa lalu dan sekarang, sampai pada tingkat tertentu dengan sifat-sifat tersebut mempunyai pengaruh yang brarti terhadap fungsi lahan oleh manusia pada masa sekarang dan masa yang akan datang.(Sitorus:2004)

Lahan produktif adalah lahan yang subur dan bisa ditanam sehingga bisa dijadikan sawah atau ladang. Sedangkan lahan yang tidak produktif adalah lahan yang tanahnya gersang atau tidak subur sehingga sulit untuk ditanami. Peraturan pemerintah tentang ketahanan pangan ini di berlakukan di kabupaten nunukan yang merupakan wilayah pertanian. Ketahanan pangan di kabupaten nunukan memiliki hubungan koordinasi antara dinas pertanian dan ketahanan pangan dengan masyrakat. Adapun beberapa hal di bawah ini yang membantu berjalannya kebijakan tersebut yaitu Perilaku hubungan antar organisasi, dimensi-dimensinya ialah komitmen dan koordinasi antar organisasi.

Penerapan kebijakan publik dalam mencapai hasil yang optimal, jarang berlangsung dalam kelompok sendiri, tanpa menggunakan organisasi lain sebagai pendukung 
atau piranti pelaksana. Implementasi kebijakan memerlukan hubungan antar organisasi untuk membawa perubahan kebijakan umum kedalam aturan yang jelas, dan ini berlangsung secara berkelanjutan dalam proses sosial yang dapat mengkonversi arah kebijakan melalui tindakan.

Dalam tataran implementasi, komitmen adalah kesepakatan bersama dengan instansi lain terkait dalam menjaga stabilisasi organisasi dan jaringan antar organisasi yang ada, dalam kaitannya dengan pelaksana program. Sedangkan

koordinasi adalah proses penyepakatan bersama yang mengikat berbagai kegiatan atau unsur yang berbeda-beda sedemikian rupa, sehingga disisi yang satu semua kegiatan atau unsure tersebut terarah pada pencapaian suatu tujuan yang telah ditetapkan dan disisi lain keberhasilan kegiatan yang satu tidak merusak keberhasilan kegiatan yang lain. Perilaku birokrasi tingkat bawah Perilaku birokrasi tingkat bawah bekerja dalam situasi yang ditandai dengan berbagai kebutuhan masyarakat. Mereka berupaya mengatasi permasalahan dan membuat perioritas kebijakan, mengontrol dan memodifikasi tujuan kebijakan berdasarkan persepsi masyarakat.

$$
\text { Michael Lipsky }
$$

mengambarkan birokrasi tingkat bawah ini sebagai "jabatan yang berhubungan langsung dengan masyarakt". Secara sustansial, mereka memiliki pertimbangan sekaitan dengan tugasnya masingmasing. Bahkan berdasarkan posisinya di tengah masyarakat itu, mereka memiliki peluang lebih besar dalam putusan kebijakan. Mereka dapat member pertimbanagan, menggunakan pengarunya di lua kewenangan formal, sebagaimana Lispky (1980) menyebut bahwa implementasi kebijakan berpengaruh lebih dominan berasal dari pekerjaa tingkat bawah ini. Adapun dimensi perilaku birokrasi tingkat bawah yaitu kontrol organisasi. Kontrol organisasi berfungsi melakukan pengawasan terhadap aktivitas masyarakat dalam menangani pangan di kabupaten nunukan, sehingga staf yang menangani ketahanan pangan dapat menjalankaan tugas dengan 
baik sesuai dengan tugas pokok dan fungsinya, seperti bekerjasama dengan masyarakat dalam memahani peraturan pemerintah dan membantu menerapkan peraturan pemerintah tersebut. Untuk mengetahui pengawasan yang dilakukan pimpinan terhadap bawahannya.

$$
\text { Selain faktor-faktor yang }
$$
bersifat mendukung dilaksanakannya kebijakan peraturan pemerintah tentang ketahanan pangan, ada pula faktor-faktor yang sifatnya penghambat yaitu perilaku kelompok sasaran. Perilaku kelompok sasaran (target grup behavior) yang tidak hanya memberi pengaruh pada efek/dampak kebijakan, tetapi juga mempengaruhi kinerja birokrat/aparat tingkat bawah. Dimensinya mencakup respon positif atau negatif masyarakat dalam mendukung atau tidak mendukung kebijakan. (Winter:2003) Perilaku kelompok sasaran yaitu orang atau sekelompok orang, atau organisasi dalam masyarakat yang perilaku atau keadaannya ingin dipengaruhi oleh kebijakan yang bersangkutan. Kebijakan publik berawal dari adanya tuntutan atau dukungan dari sekelompok orang dalam upaya mengatasi suatu permasalahan publik , maka dari itu mereka termasuk kedalam elemen penting dari dari sebuah kebijakan publik. (Tachjan 2006:35)

\section{PENUTUP}

Berdasarkan kasil penelitian yang dikemukakan pada bab sebelumnya maka penulis dapat menarik kesimpulan bahwa:

(1)Hasil penelitian menunjukkan bahwa implementasi kebijakan peraturan pemerintah nomor 68 tahun 2002 tentang ketahanan pangan di kabupaten nunukan sudah berjalan cukup baik, hanya perlu sedikit perhatian dari pemerintah untuk bantuan tani harus selalu tepat waktu agar petani tidak kesulitan dalam mengelolah pangan.(2) Adapun faktor pendukung yang mampu membantu berjalannya kebijakan tersebut. Dimensidimensinya yaitu komitmen dan koordinasi. Komitmen dan koordinasi yang di bangun oleh pihak pemerintah sudah berjalan dengan cukup baik. Kontrol organisasi atau pengawasan yang dilakukan sudah baik pimpinan 
melihat sejauh mana kinerja para stafnya melalui tugas yang diberikan dan sejauh mana para bawahannya menyelesaikan tugas tersebut agar ketahanan pangan dapat memiliki hasil yang baik. Pengawasan yang dilakukan juga melihat laporan dari hasil kinerja para bawahanya. Adapula faktor-faktor yang sifatnya poenghambat yaitu perilaku kelompok sasaran dimensinya mencakup respon positif atau negatif masyarakat dalam mendukung atau tidak mendukung kebijakan. Hanya masyarakat yang tidak bergabung di kelompok tani yang merespon negatif dengan adanya kebijakan ini.

\section{DAFTAR PUSTAKA}

Haryadi P dan Dewayanti R. 2009. Petunjuk Sederhana Memproduksi Pangan Yang Aman. Jakarta: Dian Rakyat.

Suryana, A. 2005. Kemandirian Pangan Menuju Ketahanan Pangan Berkelanjutan. Lembaga Informasi Dan Studi Pembangunan Indonesia. Jakarta.

Kartini, K., Usman, J., \& Mustari, N. (2017). Implementasi Kebijakan Perlindungan Pekerja Di Bawah Umur Di Dinas Sosial Kota Makassar. Kolaborasi: Jurnal Administrasi Publik, 3(2), 213227.
Nugroho D, Riant. 2008. PublicPolicy.

Jakarta: PT. Elex Media Komputindo.

Edward,

III.

1980.

ImplementationPublic Policy. Washington DC: Congresional Quarter Press.

Mazmanian, Deniel H, dan Paul A.

Sabatier, 1983.

Implementation and public

policy. New York:

HarperCollins.

Abdul Wahab, Solichin. 2008. Analisis Kebijakan Dari Formulasi Ke Implementasi Kebijakan Negara. Jakarta: Bumi Aksara.

Winarmo, Budi. 2007 Kebijakan Publik: Teori dan Proses. Yogyakarta: Media Pressindo.

Subarsono, AG. (2006). Analisis Kebijakan Publik:Konsep, Teori dan Aplikasi. Yogyakarta: Pustaka Pelajar.

Syahyuti. 2011. Konsep Penting dalam Pembangunan Pedesaan dan Pertanian. Bina Rena Pariwara. Jakarta.

Ali Khomsan. 2003. Pangan dan Gizi Untuk Kesehatan. Jakarta: PT. Rajagrafindo. Persada.

Dunn, N. William. 1998. Pengantar Analisis Kebijakan Publik. Jakarta: Gadjah Mada University Press.

Haryadi P dan Dewayanti R. 2009. Petunjuk Sederhana Memproduksi Pangan Yang Aman. Jakarta: Dian Rakyat.

Handako, T. Hani Handoko. 2003. Manajemen. Edisi 2. Yogyakarta: Penerbit BPFE. 
